\title{
Good practices of labor and birth care from the perspective of health professionals
}

Boas práticas de atenção ao parto e ao nascimento na perspectiva de profissionais de saúde Buenas prácticas de atención al parto y al nacimiento en la perspectiva de profesionales de salud

\section{Simone Barbosa Pereira', Claudia Maria Gabert Diaz', Marli Terezinha Stein Backes", Carla Lizandra de Lima Ferreira', Dirce Stein Backes'}

\author{
' Centro Universitário Franciscano. Santa Maria, Rio Grande do Sul, Brazil. \\ " Universidade Federal de Santa Catariana. Florianópolis, Santa Catarina, Brazil.
}

\begin{abstract}
How to cite this article:
Pereira SB, Diaz CMG, Backes MTS, Ferreira CLL, Backes DS. Good practices of labor and birth care from the perspective of health professionals. Rev Bras Enferm [Internet]. 2018;71(Suppl 3):1313-9. [Thematic Issue: Health of woman and child] DOI: http://dx.doi.org/10.1590/0034-7167-2016-0661
\end{abstract}

\section{Submission: 03-15-2017 Approval: 10-16-2017}

\begin{abstract}
Objective: Determine the understanding of health professionals of an obstetric hospital regarding the good practices of labor and birth care recommended by the World Health Organization. Method: Research-initiative, with data collection between April and July 2016 using the focal group technique, with 27 health professionals of an obstetric hospital of Rio Grande do Sul with 21 hospitalization beds. Results: Three thematic categories were achieved: good obstetric practices and their meanings; from the biological character to singular and multidimensional care; from the punctual and fragmented conception to the labor and birth care network. Conclusion: Good practices, in addition to enabling rethinking the obstetric model and contributing to organize the maternal and child health care network in order to ensure access, humane care, and problem-solving capacity, also foster female protagonism.
\end{abstract}

Descriptors: Nursing Research; Qualitative Research; Humanization of Childbirth Care; Obstetric Nursing; Patient Care Team.

\section{RESUMO}

Objetivo: Conhecer a compreensão dos profissionais de saúde de uma unidade hospitalar obstétrica referente às boas práticas de atenção ao parto e ao nascimento preconizadas pela Organização Mundial da Saúde. Método: Pesquisa-ação, cujos dados foram coletados entre os meses de abril e julho de 2016 a partir da técnica de grupo focal, de 27 profissionais de saúde de uma unidade obstétrica do Rio Grande do Sul que conta com 21 leitos de internação. Resultados: Resultaram três categorias temáticas: das boas práticas e seus significados; do caráter biológico aos cuidados singular e multidimensional; da concepção pontual e fragmentada à rede de atenção ao parto e ao nascimento. Conclusão: As boas práticas, além de possibilitarem o repensar do modelo obstétrico e contribuírem para organizar a rede de atenção à saúde materno infantil a fim de garantir acesso, acolhimento e resolutividade, estimulam o protagonismo da mulher em suas múltiplas dimensões.

Descritores: Pesquisa em enfermagem; Pesquisa qualitativa; Humanização de Assistência ao Parto; Enfermagem Obstétrica; Equipe de Assistência ao Paciente.

\section{RESUMEN}

Objetivo: Conocer la comprensión de los profesionales de salud de una unidad hospitalaria obstétrica referente a las buenas prácticas de atención al parto y al nacimiento preconizadas por la Organización Mundial de la Salud. Método: Investigaciónacción, cuyos datos fueron recogidos entre los meses de abril y julio de 2016 desde la técnica de grupo focal, con 27 profesionales de salud de una unidad obstétrica de Rio Grande do Sul que cuenta con 21 lechos de internación. Resultados: Resultaron tres categorías temáticas: buenas prácticas y sus significados; del carácter biológico al cuidado singular y multidimensional; de la concepción puntual y fragmentada a la red de atención al parto y al nacimiento. Conclusión: A las buenas prácticas, además 
de posibilitar el repensar del modelo obstétrico y contribuir para organizar la red de atención a la salud materno-infantil con el objetivo de garantizar acceso, acogida y resolutividad, estimulan el protagonismo de la mujer.

Descriptores: Investigación en Enfermería; Investigación Cualitativa; Humanización de Asistencia al Parto; Enfermería Obstétrica; Equipo de Asistencia al Paciente.

\section{CORRESPONDING AUTHOR Simone Barbosa PereiraＥ-mail: simone enfermagem@yahoo.com.br}

\section{INTRODUCTION}

Evidence shows that hypermedicalization is one of the major problems of maternal health in Brazil. Institutionalized births conducted by trained professionals reach $98 \%$, of which approximately $90 \%$ are performed by a medical professional. Unnecessary interventions without criteria persist, resulting in high maternal and child mortality rates ${ }^{(1-2)}$. The World Health Organization (WHO) estimated that approximately 289,000 women in the world lost their lives during pregnancy, childbirth, and puerperium in 2013, a global rate of 210 maternal deaths for every 100,000 live births ${ }^{(1)}$.

However, labor and birth care has undergone important and increasing changes in recent decades, at the national and international levels. One of the factors responsible for these changes was the release of the document Appropriate Technology for Birth by the WHO in $1985^{(3)}$. Thus, under this fostering movement, the good practices in labor and birth care gradually gained space in the theoretical-practical field of obstetrics seeking to reach the Millennium Development Goals, especially the improvement of health through the reduction of maternal and child mortality ${ }^{(4-5)}$.

The WHO document enabled a new way to intervene in labor and birth care based on new theoretical and practical frameworks that enabled rethinking the hegemonic intervention model, centered on fragmentation and verticalization of the professional actions. The normal childbirth care practices, which were classified into categories related to usefulness, effectiveness, and risk: the demonstratively useful practices that should be encouraged; the clearly harmful or ineffective practices that should be avoided; those with little evidence and that should be used with caution; and those that are often used inappropriately ${ }^{(5)}$.

Improving the quality of obstetric care in order to reduce maternal and child mortality, as recommended by the WHO, will only be possible through renewal of the hegemonic obstetric model, especially by fostering non-invasive care technologies. To this end, it becomes urgent that obstetric health professionals, specifically obstetric nurses, are engaged and committed to the necessary changes, contributing to the achievement of the Millennium Development Goals ${ }^{(6)}$.

Considering the incorporation of good practices of labor and birth care in $\mathrm{WHO}$ recommendations and reinforced by the Ministry of Health by the inducing policy called Stork Network (Rede Cegonha in Portuguese), and the consequent reduction of unnecessary interventions, this study has the following guiding question: what is the understanding of health professionals of an obstetric hospital regarding the good practices of labor and birth care recommended by the WHO?

\section{OBJECTIVE}

Recognizing the need to establish a new manner of professional thinking and acting, capable of transcending the punctuality and linearity of the verticalized obstetric practices and that enable female protagonism, this study aimed to determine the understanding of health professionals of an obstetric hospital regarding the good practices of labor and birth care recommended by the WHO.

\section{METHOD}

\section{Ethical aspects}

This research project was approved by the Research Ethics Committee. In order to maintain the anonymity of participants, their reports were identified with names of precious stones, by suggestion of the professionals interviewed themselves.

\section{Theoretical-methodological framework}

An increasing paradigmatic movement is observed in the field of labor and birth care based on technologies founded on advanced scientific practices. Accordingly, through the document Appropriate technology for birth, the WHO brought important contributions so as to improve the quality of obstetric care and reduce child mortality, as proposed by the United Nations $(\mathrm{UN})^{(3)}$. In order to improve the quality of the conduct of labor, delivery, and birth, the WHO developed a document with the classification of the good practices of labor and birth care, covering the practices to be developed, the practices that should be discouraged, and also those that require better scientific contribution for the development of labor and birth care ${ }^{(5)}$.

It is considered that, even with this document inducing good practices, unnecessary interventions persist which have culminated in a still high maternal mortality ratio (MMR), despite the decline reported in 2013 by the UN. This same report points out that Brazil did not reach the goal set for 2015 of reducing maternal deaths to 35 per 100,000 live births, making joint actions necessary so as to stimulate changes in the current obstetric care model based on the adoption of appropriate technology for birth ${ }^{(6)}$.

\section{Type of study}

This is an extended research initiative project developed with the purpose of implementing the good practices of labor and birth care recommended by the WHO in an obstetric hospital of a midsize institution of the central region of the state of Rio Grande do Sul.

Research-initiative is a tool that promotes the inclusion and transformation of the praxis in a gradual and participatory manner, considering the empirical aspect through needs 
determined by the individuals collectively, in order to enable strategies capable of modifying situations ${ }^{(7)}$.

\section{Methodological procedures}

\section{Study setting}

This study presents the results of the first step of the research-initiative, whose objective was to determine the understanding of health professionals of an obstetric hospital regarding the good practices of labor and birth care.

\section{Data source}

This study included 27 health professionals, divided into three groups, of a regional obstetric hospital with 21 beds for hospitalization of normal risk: 7 obstetric nurses, 14 nursing technicians, 4 resident nurses in obstetric nursing, and 2 obstetricians. The inclusion criteria were: currently working in the obstetric hospital team and having time to participate in the three focal meetings; the exclusion criteria were: being under supervision scheme, on vacation, on sick leave, and/or unavailable to participate in the three meetings.

\section{Data collection and organization}

The data were collected through the focal group technique, which allows in-depth discussions related to a particular theme of common interest of the participants. Through these discussions, the research respondents seek to learn more about a specific phenomenon and expand the possibilities of changing preconceived opinions ${ }^{(8)}$.

Three focal meetings were held between April and July 2016 in a room of the obstetric hospital, after the daytime and nighttime shifts, in order to increase the participation of the professionals. Each focal meeting lasted about 1 hour, being coordinated by the lead researcher, supported by an observer in charge of the recordings and notes.

\section{Study Steps}

In the first focal meeting, the participants were invited by the coordinator to express in a blank sheet of paper, in a descriptive or illustrative manner, their understanding about the good obstetric practices. Then, each participant was invited to share their understanding spontaneously. Subsequently, the coordinator presented to them, using slides, the good obstetric practices recommended by the $\mathrm{WHO}$ and invited them to an expanded discussion on the subject.

In the second focal meeting, held the following week, the coordinator sent to the participants, in advance, by e-mail, frameworks related to the good obstetric practices discussed in the first meeting, and instigated them to conduct a criticalreflexive analysis about the process of their implementation in the hospital in question. Based on the collective discussions, the analysis was deepened on scientific evidence and, later, the good practices were implemented.

In the third and last meeting, held three weeks after the second, there was discussion on the advantages and disadvantages of implementing the good practices in the hospital, from the perspective of the participants. In each meeting the participants' reports were recorded by the observer, and the main ideas were noted.

\section{Data analysis}

The data were analyzed through the thematic content analysis technique proposed by Bardin ${ }^{(9)}$, which sets three phases: the pre-analysis, seeking a first impression of the data collected, subdivided into four stages (reading, choice of documents, hypotheses, objectives and preparation of indicators); the exploratory phase, in which the material is coded into categories by using selections of the records; and the third and final phase, in which the data are processed through critical and reflective evaluation.

\section{RESULTS}

With the data analysis three thematic categories were achieved: good obstetric practices and their meanings; from the biological character to singular and multidimensional care; and from the punctual and fragmented conception to the labor and birth care network.

\section{Good obstetric practices and their meanings}

It was observed, in the description of the participants, that they have knowledge of the good practices and their meanings, as they transcend technical and punctual issues, in which they recognize the importance of non-invasive technologies and, mainly, when they mention that the woman must be considered subject and participant of the parturition process.

Thus, the professionals indicated the importance of sensitivity and humane care, of listening attentively to the doubts and concerns of women, of including the family and/or companion in the different stages, and especially of making every event of women singular, as in the following reports:

I understand that are part of the good practices of labor and birth the timely cord clamping, the free choice of companion by the mother, right, the free position of the woman in labor, preferably in a verticalized manner, skin-to-skin contact of the newborn with the mother, breastfeeding in the first hour of life, besides stimulating for the birth to be as physiological as possible, that is, without the routine use of episiotomy and oxytocin. (Jasper)

I think we have to serve the pregnant woman when she arrives in the hospital with attention, with care and respect, because they deserve it... there are places where they are not treated properly, with respect, even with respect to pain. Sometimes we complain, you know, because some of them make too much fuss, but you have to take into account that each person knows the intensity of their pain, right. (Topaz)

The health professionals also recognize that pregnant women must be provided with the means to be able to make consistent choices. Therefore, the participants associated the good practices to well-informed and clarified prenatal consultation, so the pregnant woman is aware of her physiological condition and assume co-responsibility for the processes of labor and birth. 
Informed woman, right, aware of what's going to happen, I mean, that's part of prenatal care... pregnant women need to be informed about what might happen, as in the use of noninvasive technologies, right. She needs to be informed about ambulation, birthing ball, warm bath, horse [rocking birthing chair] ... everything that we do here in the unit. (Garnet)

Good practices of labor and birth care, in the understanding of the health professionals, are mainly related with the light technologies for health care, that is, well-conducted prenatal guidelines, humane care, and women's free choice not only in the different stages, but also in the inclusion of the family and/ or companion in the parturition process.

\section{From the biological character to singular and multidimen- sional care}

In their reports, the participants emphasize the importance of active and conscious participation of women in labor, showing the understanding that the good practices of care are part of the singular and multidimensional care, that, they are capable of transcending the biological character, reaching the human singularity.

In this process, in particular, the nursing professionals are differentiated, appearing as promoters and stimulators of good obstetric practices by fostering female autonomy and protagonism, as well as by encouraging bonding, empathy, and humane care. The reports show that the nursing professionals tended to be more sensitive and open to new possibilities for intervention, since this posture can be verified in practice, as follows:

The main thing, that's changed quite a bit, let's say, is related to the respect for the pregnant and parturient woman, as to the possibility of them deciding what they want. Once it was imposed, it was like this and that, and that's over, now they do it all, in fact, we encourage them... (Pearl)

We encourage them to choose, which doesn't always happen, right? It's not every professional who allows, but I think that nursing is more focused today, because before we also thought we had to impose to them, and today we act differently. (Agate)

Singular and multidimensional care in obstetric care makes it possible to go beyond the fragmented and mechanized techniques and/or practices. The participants generally recognized that care involves understanding the human singularity and multidimensionality, and that each woman is driven by dreams and expectations that must be treated humanely and respected.

We need always treat women humanely and as best as possible. You need to respect their pain and distress. Try to be as friendly as possible, always being professional, explain the doubts, right, and the operation of the hospital, how labor works here. (Amethyst)

Sometimes we go beyond our working guidelines, you know? And end up being a bit of a psychologist, a little bit of everything, because we have to give her humane care in the best possible way... define our conduct then and base it on scientific evidence... to ensure the mother's and baby's well-being, not doing things based on speculations, right? (Jade)
In order to provide singular and multidimensional care, the participants emphasize the importance of a multidisciplinary team, in which each professional has a function, but that at some point they intertwine and complement one another aiming to provide a care focused on the human singularities. Transcending the biological dimension means, at the same time, making the care singular and enhanced through the view and activity of the different professionals that compose the health team.

Professional knowledge and professional update were considered by the participants as essential for the promotion of singular care. Scientific evidence should, therefore, be understood and encouraged as mainstay of safe and quality care.

From the punctual and fragmented conception to the labor and birth care network

In general, all participants recognized the importance of multidisciplinary activity and network care, understanding that good practices of labor and birth care are not reduced to a single sector and/or service, but comprise a network of relations and associations whose different points need to interact to enhance the network in its entirety. As can be observed in:

I think that to develop the good practices there must be quality and continuous prenatal care... it does not help that the patient arrives with no information and not having had access to all exams required... all of this slows down the discharge, right? (Diamond)

Respect for the women and the family, access to all the guidelines of the SUS [Unified Health System]... because here we work with the SUS health care, ensuring quality care for both mother and baby, and also for the family, you know? In order for the baby and the mother to be well, we need to have continuity and problem-solving capacity... (Turquoise)

Therefore, it was shown that the participants understand the relevance of the effective introduction of good practices in the obstetric hospital, due to the possibility of expanding the perception of care and encouraging the active participation of women in this process. The importance of a participatory care in order to provide care in accordance with the singularity of each woman and family was reinforced, as can be observed in the following report:

Much has been improved, but still not everyone can work in an integrated and continuous way... each one still wants to focus on their space and there they believe they do the best.... If everybody worked in network, the problem-solving capacity would be much greater. (Sapphire)

The participants showed in their reports that the fragmentation of care is not yet overcome. According to the respondents, many professionals struggle to transcend their space of activity and promote associations that promote collective initiatives in order to ensure the continuity and problem-solving capacity in health care.

\section{DISCUSSION}

The results of this study allow arguing that the good practices of labor and birth care are related with (re)thinking the 
intervention model and with fostering the recognition of the scientific evidence, in order to reinstate the female protagonism in the obstetric setting. Therefore, labor and birth should be considered as phenomena that transcend the strictly biological issues, aiming to achieve a social meaning that covers both cultural and economic aspects and the understanding of values, beliefs, cultures, and professional attitudes ${ }^{(10)}$. Thus, this process cannot be reduced to a mechanical and/or punctual action, since each woman/family is singular and multidimensional. This requires, from the professionals, knowledge and practices based on scientific evidence and human principles ${ }^{(11)}$.

Under this circular and dynamic movement in which the woman is the protagonist, the WHO brought important contributions, of which many practices need to be encouraged and many other discouraged due to the lack of scientific evidence that corroborate their use ${ }^{(12)}$. The practices to be encouraged and that have been corroborated in previous studies include the partogram, provision of liquids to be taken orally during labor, non-invasive methods for pain relief, freedom of position and movement of the woman in labor, skin-to-skin contact between mother and baby, and breastfeeding in the first hour of life ${ }^{(12-13)}$. The ineffective or harmful practices in the conduct of normal delivery that need to be discouraged include the use of enema, shaving, routine prophylactic catheterization, the Valsalva maneuver during the second stage of labor, and the perineal distension maneuver ${ }^{(13)}$.

There are also practices without scientific evidence: early and routine amniotomy, early clamping of the umbilical cord, routine use of oxytocin, and controlled cord traction in the third stage of labor, among others. In addition, there are known mistakenly used practices, discouraged by the participants of this study, as well as by another, previous study ${ }^{(13)}$ : uterine dynamics correction by means of oxytocic drugs without clinical indication, frequent vaginal exams, routine use of episiotomy, rigidity in the duration of the second stage of labor, among others.

It is advocated, in this perspective, the importance of scientific evidence for the use of good practices of labor and birth care, which, although incipient, should be considered essential for the development of a new culture in obstetric care, as demonstrated by previous studies ${ }^{(12-13)}$. The good practices, among other benefits, dissociate the technocratic model of care from the mother-baby binomial and foster the practices based on scientific evidence, which impact on the quality in the humanized care of both the woman and the newborn ${ }^{(13-14)}$.

Among the good practices, they also referred to the presence of a companion of choice of women during labor and birth. The participants of this study recognize that the presence of the companion is extremely relevant in the parturition process, due to the possibility of strengthening the bond between the mother, the baby, and the family. The paternal presence, above all, as mentioned by the participants and corroborated by other researches, provides the opportunity for the father to contribute effectively in the sharing of responsibilities. The presence of fathers during pregnancy, labor, and birth has been increasingly observed, which shows a social and cultural evolution ${ }^{(15-16)}$.
In order to provide humanized and quality obstetric care, according to criteria established by the Ministry of Health, there is urgent need for the organization of the services' routines to avoid unnecessary interventions. It is observed that the promotion of autonomy and privacy of women is essential, based on dialogue and on their active participation in the decisions related with the care provided and with the possible changes of conduct ${ }^{(17)}$.

In order to foster the good obstetric practices and ensure the right to safe care for both the mother and the baby, the promotion of woman and child health care networks is paramount to strengthen their autonomy and contribute to the reduction of risks. This assumption is consistent with the Stork Network, a policy recently launched by the Ministry of Health in order to reduce maternal mortality through initiatives aimed at ensuring the rights of women, from family planning to pregnancy, childbirth, and puerperium, with follow-up of the child from 0 to 24 months of age ${ }^{(18)}$.

As shown in the data of this research, the obstetric setting has undergone paradigmatic changes. The obstetric nurse has assumed an important function due to providing care focused on the needs of women during labor and delivery, using noninvasive technologies, so as to provide the minimum of unnecessary interventions ${ }^{(19)}$.

In this paradigmatic process, the obstetric nurse increasingly occupies an important space of professional activity. In addition to assisting the mother and encouraging normal delivery, the obstetric nurse determines the occurrence of dystocias and provides care to ensure the quality of the procedure and safety of mother and baby. Therefore, it can be argued that the obstetric nurse has, in addition to technical training, skills to ensure an interactive and friendly environment for the different actors involved in labor, delivery, and birth ${ }^{(20-19)}$.

To this end, female protagonism need to be reinstated in the obstetric setting by the promotion of good practices of labor and birth care; the singular and multidimensional care need to be enhanced by overcoming the fragmentation and linearity of obstetric actions and interventions; and health professionals need to be committed, in order to enhance the different initiatives of the network, for completeness, continuity, and problem-solving capacity of care actions.

\section{Study limitations}

We considered as limitations of this study the impossibility of participation of all professionals involved in the labor and birth care network in the obstetric setting, as it is understood that only teamwork is capable of transforming the obstetric care. Accordingly, cooperative research between the primary health care and hospital care is suggested, so as to strengthen the care network and ensure the problem-solving capacity from prenatal care to delivery, birth, and healthy development of the child.

\section{Contributions to the field of Nursing}

The results of this research showed that the good practices, combined with the involvement of the multidisciplinary team, can contribute to the change of paradigms in the obstetric setting. Thus, this research can contribute to other studies in the 
field of obstetric nursing, in order to improve the quality of obstetric and neonatal care aiming to achieve the government proposals through effective implementation of the good practices in the conduct of labor and birth recommended by the WHO.

\section{FINAL CONSIDERATIONS}

In addition to enabling rethinking the obstetric model and contributing to organize the maternal and child health care network in order to ensure access, humane care, and problem-solving capacity, the good practices of labor and birth care foster female protagonism in its multiple dimensions.

Beyond government initiatives, it is necessary that health professionals take co-responsibility and assume these good practices as possibility of transformation of the obstetric model. This objective requires appropriating the frameworks that support the singular and multidimensional practices in the obstetric field and promote the care network in order to ensure to women the right to humane care in pregnancy, childbirth, and puerperium, and, to the child, the right to safe birth and healthy development.

\section{REFERENCES}

1. World Health Organization - WHO. Trends in maternal mortality: 1990-2013. Estimates by WHO, UNICEF, UNFPA, the World Bank and the United Nations Population Division [Internet]. Geneva: WHO; 2014[cited 2017 Feb 04]. Available from: http://apps. who.int/iris/bitstream/10665/112682/2/9789241507226_eng.pdf?ua =

2. Victora CG, Aquino EM, Carmo LM, Monteiro CA, Barros FC, Szwarcwald CL. Maternal and child health in Brazil: progress and challenges. Lancet [Internet]. 2011[cited 2017 Feb 04];377(9780):1863-76. Available from: https://www.ncbi.nlm.nih.gov/ pubmed/21561656

3. World Health Organization - WHO. Appropriate Technology for Birth, Lancet [Internet]. 1985[cited 2016 Sep 01];2(8452):436-7. Available from: https://www.ncbi.nlm.nih.gov/pubmed/2863457

4. Andrade M, Lima J. O modelo obstétrico e neonatal que defendemos e com o qual trabalhamos. In: Brasil. Ministério da Saúde. Humanização do parto e do nascimento [Internet]. Universidade Estadual do Ceará. Brasília: Ministério da Saúde. (Cadernos Humaniza SUS). vol.4. 2014[cited 2017 Feb 04]. Available from: http://www.redehumanizasus.net/sites/default/files/caderno_ humanizasus_v4_humanizacao_parto.pdf

5. Carvalho EMP, Göttems LBD, Pires MRGM. Adherence to best care practices in normal birth: construction and validation of an instrument. Rev Esc Enferm USP[Internet]. 2015[cited 2016 Sep 01];49(6):889-97. Available from: http://dx.doi.org/10.1590/ S0080-623420150000600003

6. Instituto de Pesquisa Econômica Aplicada - IPEA. Secretaria de Planejamento e Investimentos Estratégicos. Grupo Técnico para o Acompanhamento dos ODM. Objetivos de Desenvolvimento do Milênio: relatório nacional de acompanhamento [Internet]. Brasília: Ipea: MP, SPI, 2014[cited 2016 Sep 01]. 208p. Available from: http://www.ipea.gov.br/portal/

7. Koerich MS, Backes DS, Sousa FGM, Erdmann AL, Alburquerque GL. Pesquisa-ação: ferramenta metodológica para a pesquisa qualitativa. Rev Eletr Enf[Internet]. 2009[cited 2016 Sep 01];11(3):717-23. Available from: http://www.fen.ufg.br/revista/v11/n3/ v11n3a33.htm

8. Backes DS, Colomé JS, Erdmann RH, Lunardi VL. Grupo focal como técnica de coleta e análise de dados em pesquisas qualitativas. Rev Mundo Saúde[Internet]. 2011[cited 2016 Sep 01];438-42. Available from: http://bvsms.saude.gov.br/bvs/artigos/grupo_focal_ como_tecnica_coleta_analise_dados_pesquisa_qualitativa.pdf

9. Bardin L. Análise de conteúdo. Lisboa, Portugal: Edições 70; 2011.

10. Agência Nacional de Saúde Suplementar - ANS. O modelo de atenção obstétrica no setor de Saúde Suplementar no Brasil: cenários e perspectivas. Agência Nacional de Saúde Suplementar. Rio de Janeiro: ANS, 2008[cited 2016 Sep 01]. p. 158. Available from: http://www.ans.gov. br/images/stories/Materiais_para_pesquisa/Materiais_por_assunto/ProdEditorialANS_O_Modelo_da_atencao_obstetrica_no_setor_da_SS.pdf

11. Brasil. Ministério da Saúde. Secretaria de Políticos de Saúde. Área Técnica de Saúde da Mulher. Parto, aborto e puerpério: assistência humanizada à mulher [Internet]. Ministério da Saúde, Secretaria de Políticas de Saúde, Área Técnica da Mulher. Brasília: Ministério da Saúde, 2001[cited 2016 Sep 01]. Available from: http://bvsms.saude.gov.br/bvs/publicacoes/politica_nac_ atencao mulher.pdf

12. Silva DC, Rodrigues ARG, Pimenta CJL, Leite ES. Perspectiva das puérperas sobre a assistência de enfermagem humanizada no parto normal. REBES[Internet]. 2015[cited 2017 Feb 4];5(2):50-6. Available from: http://www.gvaa.com.br/revista/index.php/ REBES/article/view/3660

13. Organização Mundial de Saúde - OMS. Maternidade segura. Assistência ao parto normal: um guia prático. [Internet] Genebra: OMS, 1996[cited 2017 Feb 4]. Available from: http://abenfo.redesindical.com.br/materias.php?subcategoriald $=2 \& i d=56 \&$ pagina $=1 \&$

14. Rocha IMS, Oliveira SMJV, Schneck CA, Riesco MLG, Costa ASC. O partograma como instrumento de análise da assistência ao parto. Rev Esc Enferm USP [Internet]. 2009[cited 2017 Feb 4];4(43):880-8. Available from: http://www.scielo.br/pdf/reeusp/ v43n4/en a20v43n4.pdf

15. Perdomini FRI. A participação do pai como acompanhante da mulher no processo de nascimento [Dissertação]. Porto Alegre, RS: Escola de Enfermagem, Universidade Federal do Rio Grande do Sul; 2010. 
16. Dodou HD, Rodrigues DP, Guerreiro EM, Guedes MVC, Lago PN, Mesquita NS. The contribution of the companion to the humanization of delivery and birth: perceptions of puerperal women. Esc Anna Nery Rev Enferm [Internet]. 2014 [cited 2016 Oct 26];18(2):262-9. Available from: http://www.scielo.br/pdf/ean/v18n2/en_1414-8145-ean-18-02-0262.pdf

17. Brasil. Ministério da Saúde. Manual técnico pré - natal e puerpério: atenção qualificada e humanizada [Internet]. Brasília, MS: 2006 [cited 2017 Feb 4]. Available from: http://bvsms.saude.gov.br/bvs/publicacoes/manual_pre_natal_puerperio_3ed.pdf

18. Silva NCM, Ruela LO, Resck ZMR, Andrade MBT, Leite EPRC, Silva MMJ, et al. Humanização da assistência de enfermagem em uma unidade de internação obstétrica. Rev Enferm Foco [Internet]. 2013[cited 2016 Jan 30];4(2):88-91. Available from: http:// revista.cofen.gov.br/index.php/enfermagem/article/view/518

19. Costa MCMD. Configurando o modelo da prática do cuidado do enfermeiro obstetra à mulher no parto hospitalar: revelando contradições e possibilidades[Tese] [Internet]. Universidade Federal de Santa Catarina, Centro de ciências da saúde. Programa de Pós Graduação de Enfermagem. Florianópolis-SC, 2015[cited 2017 Feb 4]. 352p. Available from: https://repositorio.ufsc.br/xmlui/ bitstream/handle/123456789/158818/337077.pdf? sequence $=1$ \&isAllowed $=\mathrm{y}$

20. Pereira ALF, Progianti JM, Alves VH, (Orgs.). Legislação profissional e marcos regulatórios da prática assistencial da enfermeira obstétrica no Sistema Único de Saúde. In: Associação Brasileira de Obstetrizes e Enfermeiros Obstetras - ABENFO Nacional [Internet]. Rio de Janeiro: Centro de Estudos da Faculdade de Enfermagem da UERJ, 2010[cited 2017 Feb 4]. Available from: http:// pt.calameo.com/books/0022538091c7bfa34ea00 